\title{
PERSPEKTIF ILMIAH DAN KEYAKINAN TERHADAP EVOLUSI MAHASISWA BIOLOGI DI UNIVERSITAS BERBASIS AGAMA
}

\section{SCIENTIFIC PERSPECTIVE AND FAITH TOWARDS EVOLUTION BIOLOGY STUDENTS IN RELIGION BASED UNIVERSITIES}

\author{
T A Helmi'ia, N Y Rustaman 2, F S Tapilouw ${ }^{2}$, T Hidayat ${ }^{2}$ \\ ${ }^{1}$ Faculty of Teacher Training and Education Djuanda University , \\ Jl. Tol Ciawi No. 1, Kotak Pos 35 Ciawi, Bogor 16720. \\ ${ }^{2}$ Biology Education Department, Indonesia University of Education Jl. \\ Dr. Setiabudi No 229. Bandung 40154, Indonesia. \\ a Korespondensi: Helmi, E-mail: Helmia.suwarjono@gmail.com \\ (Diterima: 15-07-2019; Ditelaah: 17-07-2019; Disetujui: 09-09-2019)
}

\begin{abstract}
Evolution is a crucial keyword to discuss concerning beliefs in various religions. In Indonesia as the country with the largest Muslim population in the world, evolution is a fairly sensitive issue and controversy. This study conducted a study of the views of students at Islamicbased universities on the concept of evolution. This study uses a case study methodology with 36 students majoring in biology as a key informant and involves one lecturer as other information. The results obtained in this study were that most respondents believed in evolution as the origin of the diversity of living things, but opposed the theory of the origin of life, especially the concept of "common ancestor." The most surprising finding was that even though they did not believe in some parts of the theory of evolution, they stated that they would still teach it when they were teachers.

Keywords: Belief, Evolution, Scientific perspectives.
\end{abstract}

\begin{abstract}
ABSTRAK
Evolusi merupakan kata kunci yang sangat krusial untuk dibahas dalam kaitannya dengan keyakinan di berbagai agama. Di Indonesia sebagai negara dengan penduduk muslim terbesar di dunia evolusi adalah isu yang cukup sensitif dan kontroversi. Penelitian ini melakukan studi terhadap pandangan mahasiswa di Universitas berbasis Islam terhadap konsep evolusi. Penelitian ini menggunakan metodologi studi kasus dengan informan kunci adalah 33 mahasiswa jurusan biologi serta 1 orang dosen sebagai informan tambahan. Hasil yang diperoleh dalam penelitian ini adalah sebagian besar responden mempercayai evolusi sebagai asal usul keberagaman makhluk hidup, namun menentang teori tentang asal usul kehidupan terutama konsep "common ancestor". Temuan yang paling mengejutkan dalam penelitian ini adalah meskipun mereka tidak percayai beberapa bagian dari teori evolusi, mereka menyatakan akan tetap mengajarkannya ketika telah menjadi guru.
\end{abstract}

Kata Kunci : Evolusi, Keyakinan, Pandangan Ilmiah.

Helmi, T. A, Rustaman, N, Y., Tapilouw, F, S., \& Hidayat, T. (2019). Perspektif Ilmiah dan Keyakinan Terhadap Evolusi Mahasiswa Biologi di Universitas Berbasis Agama. Jurnal Sosial Humaniora, 10(2), 83-92. 


\section{PENDAHULUAN}

Evolusi merupakan bagian ilmu biologi yang dianggap cukup penting. Pada sekolah umum yang tidak berbasis agama, evolusi merupakan mata kuliah wajib. Meskipun demikian evolusi hanya mendapatkan tempat yang tidak begitu besar dikarenakan mata kuliah ini tidak melakukan praktik, murni semuanya teori. Evolusi adalah sejarah perkembangan makhluk hidup dimana banyak orang yang menganggap sejarah adalah bagian yang penting yang tidak bisa dipisahkan dari fakta terkini tentang suatu hal. Di banyak penelitian, ditemukan bahwa tidak semua konsep yang berhubungan dengan evolusi ditentang oleh kalangan umum dan akademisi. Sebagian besar ilmu evolusi yang tidak mengaitkan antara kehidupan manusia dan asal usulnya, nyatanya dapat diterima oleh masyarakat. Tingkat pengetahuan pendidik yang rendah dan latar belakang pengetahuan yang salah dan mengalami miskonsepsi adalah faktor paling utama menyebabkan penolakan kepada konsep-konsep evolusi. Penolakan terhadap konsep evolusi terjadi pada masalah yang mengandung topic asal usul manusia. Pada topik ini, sebagian besar anggapan menyatakan bahwa manusia berasal dari kera. Peneliti pendahulu menyebutkan bahwa bahkan guru sains pun sering merasa tidak nyaman dengan topik pengajaran seperti evolusi karena evolusi kontroversial secara sosial, kebanyakan dari mereka tidak ingin menyinggung siswa, atau berbeda pandangan dengan orang tua mereka, bahkan administrasi di bawah tempat mereka bekerja (Asghar et al. 2007; Jackson et al. 1995; Schilders et al. 2009; Owens et al, 2017).

Penolakan ini tentu lebih besar lagi ditemukan oleh peneliti dinegara-negara dengan tingkat keagamaan yang taat/kuat. Tidak hanya di Indonesia, di negara lain baik di kawasan Asia, negara-negara Eropa maupun Amerika dan Australia, evolusi juga mengalami penentangan yang keras (Atanasiou, dkk, 2014). Pandanganpandangan pro dan kontra kepada teori evolusi hingga sekarang ini masih terjadi menyeluruh di lingkungan para ilmuwan, kalangan terdidik, pemuka agama hingga masyarakat umum. pandangan yang tidak sama terhadap teori evolusi muncul dikarenakan perbedaan cara pandang ketika mempelajari teori evolusi. pandangan evolusi makhluk hidup dari sisi filsafat dan keyakinan hingga saat ini dipandang sebagai sesuatu hal yang bertolak belakang dengan teori evolusi (Afidah, 2012). Akan tetapi teori ilmiah apa pun sesungguhnya tidak dapat meniadakan Tuhan. Beberapa pandangan ateistik atas teori ilmiah merupakan bentuk dari "saintisme", yaitu keyakinan yang menjadikan sainslah sebagai satu-satunya cara untuk mempelajari pengetahuan. Saintisme memandang bahwa hanya alam (material) satu-satunya realitas yang ada (Luthfi \& Khusnuryani, 2005). Peneliti terdahulu mengungkapkan bahwa penentangan pada teori evolusi yang juga ditemukan oleh banyak peneliti yaitu bukan hanya didasarkan pada faktor perbedaan pandangan dari sisi keyakinan (agama) saja, akan tetapi alasan yang sangat mendasar mengenai sulitnya materi ini untuk dipelajari di sekolah adalah bersumber dari kemampuan dan kapasitas pengetahuan guru (Saputra, 2017).

Evolusi di dunia sangat kontroversi dan mengalami banyak penentangan. Di mulai pada level yang terendah hingga level pendidikan tertinggi. Sebelum kita melihat pada tingkat SMA dan Universitas, kita lihat terlebih dahulu dari dasar dimana Guru sekolah dasar memainkan peran penting dalam memutus siklus kontroversi evolusi yang berkelanjutan. Mereka memiliki kapasitas untuk memperkenalkan konsepkonsep pada saat yang sama para siswa dapat pertama kali menemukan pesan anti revolusi. Studi ini membandingkan religiusitas, penerimaan, dan pemahaman evolusi jurusan pendidikan dasar dengan jurusan lain. Hasil penelitian menunjukkan bahwa jurusan pendidikan dasar mempertahankan tingkat religiusitas yang tinggi dan penerimaan yang jauh lebih 
rendah dibandingkan dengan jurusan lain yang tidak ditugaskan mengajar evolusi di sekolah umum Amerika. Jurusan pendidikan dasar mempertahankan tingkat pemahaman evolusi yang tidak jauh lebih tinggi dari pada mereka yang tidak berencana mengajar siswa sekolah dasar (Herman, 2016). Hal ini mengindikasikan bahwa memutus mata rantai penolakan semakin akan menjadi pekerjaan berat. Pandangan ini mendorong peneliti untuk menyelidiki seberapa kuat pengaruh keyakinan seseorang terhadap penolakan ataupun penerimaannya terhadap evolusi dan alasan apa yang mendasarinya dalam mengambil keputusan terhadap pendapatnya tersebut. Serta bagaimana pandangan dan sikap dosen pengampu mata kuliah memposisikan dirinya dalam menghadapi situasi evolusi yang memang secara fakta menunjukkan konflik pemikiran yang berkepanjangan pada saat seorang pendidik harus menyampaikan hal ini kepada peserta didiknya sendiri. Bagaimanakah dosen sebagai pengampu mata kuliah menyikapi hal ini dan melaksanakan perkuliahan evolusi dikelasnya.

\section{MATERI DAN METODE}

Penelitian ini menggunakan pendekatan deskriptif kualitatif studi kasus (case study). Penelitian studi kasus tidak hanya menjawab pertanyaan penelitian mengenai 'apa' (what) objek yang diteliti, akantetapi lebih kompleks dan komprehensif lagi meliputi 'bagaimana' (how) dan 'mengapa' (why) suatu hal/kasus bisa terjadi (Yin, 2009). Kualitatif memiliki karakterisktik: terjadi pada latar alamiah baik tempat kejadian maupun prilaku, tidak meminta teori sebagai dasar dan hasil, peneliti adalah instrumen utama di dalam penelitian, hasil penelitian dilaporkan secara deskriptif, fokus diarahkan pada persepsi dan pengalaman responden atau informan, proses sangat penting dan menjadi data yang setara dengan produk atau hasil, peneliti dituntut memunculkan pola dan merkonstruksi jawaban responden, data tidak dikuantifikasi, objektivitas hasus sangat dijunjung tinggi (Cresswell, 2007) Pelaksanaan penelitian ini dilakukan selama 3 bulan di sebuah sekolah tinggi berbasis agama Islam di Kota Bogor. Data hasil penelitian diperoleh melalui wawancara dan pemberian angket terhadap key informan dan responden sebagai narasumber. Key informan dalam penelitian ini adalah mahasiswa program studi pendidikan biologi dan informan lainnya adalah 1 (satu) orang dosen pengampu mata kuliah evolusi. Adapun secara detail prosedur pengumpulan data dilakukan melalui observasi langsung, observasi partisipan, wawancara serta pemberian angket. Untuk teknik pengujian keabsahan data dilakukan dengan mencari siklus kesamaan data, ketekunan penelitian, triangulasi, diskusi, serta mencari kelengkapan referensi yang berkaitan.

\section{HASIL DAN PEMBAHASAN}

\section{Hasil Temuan Penelitian}

Materi evolusi berkaitan dengan kurikulum pada mata kuliah bersumber dari Learning Outcome (LO) pada KKNI. Dosen pengampu mata kuliah juga berpedoman pada rekomendasi standar Konsorsium Biologi Indonesia (KOBI). Mahasiswa sebagai sumber data utama adalah merupakan mahasiswa program studi pendidikan biologi dengan latar belakang agama atau keyakinan yaitu islam. Keyakinan ini yang menjadi dasar utama dalam menentukan pemahaman dan penerimaan terhadap beberapa konsep yang dianggap cukup diragukan kebenarannya. Penelitian menemukan bahwa meskipun ada konsep yang tidak diyakini atau ditolak oleh mahasiswa sebagai sebuah kebenaran, akan tetapi tingkat penguasaan dan pemahaman konsep siswa secara keseluruhan materi atau topik dalam perkuliahan evolusi sangat baik. Mahasiswa sebagian besar menolak konsep common ancestor yang oleh mereka dianggap sebagai konsep yang mengarahkan pada pemikiran bahwa kera 
adalah nenek moyang dari manusia (perspektif mahasiswa).

\section{Pembahasan Temuan Penelitian}

Penelitian ini menemukan beberapa hal yang menyangkut akan adanya penerimaan dan indikasi penolakan terhadap teori evolusi, terutama penolakan menyangkut asal usul makhluk hidup (asal-usul manusia) dan penerimaan terhadap konsep yang lainnya.

\section{Materi Evolusi Dalam Standar Kurukulum dan Aplikasi Pada Program Studi}

Evolusi adalah merupakan mata kuliah wajib bagi mahasiswa pendidikan biologi, hal ini tidak terkecuali bagi mahasiswa tempat diadakan penelitian ini. Materi perkuliahan evolusi di setiap Universitas diselaraskan pada Standar Konsorsium Biologi sebagai acuan lainnya disamping standar acuan utama/dasar yaitu kurikulum KKNI. Konsorsium biologi (KOBI) merupakan forum pertemuan para ilmuan bidang biologi di Indonesia. Dimana konsorsium ini melahirkan banyak kesepakatan-kesepakatan melalui penelaahan terhadap kurikulum dan sistem pendidikan dan pengajaran bidang biologi. Adapun rincian materi evolusi yang menjadi rujukan berdasarkan hasil kajian awal terdapat pada Tabel 1

Tabel 1. Kajian Materi Evolusi

\begin{tabular}{lll}
\hline Materi & Materi & Materi Evolusi \\
Evolusi & Evolusi & yang diajarkan \\
Rekomenda & Analisa & pada \\
si KOBI & kurikulum di & Universitas \\
& jurusan & \\
& pendidikan & \\
& biologi pada & \\
& 5 Universitas & \\
& di Indonesia & \\
\hline Menguasai & Mekanisme & 1.hakikat \\
teori & evolusi & evolusi, sejarah \\
biologi, & Asal usul & waktu geologi \\
mencakup & kehidupan & dan keadaan \\
tingkat & Seleksi alam & bumi awal \\
kajian & sel & \\
\hline
\end{tabular}

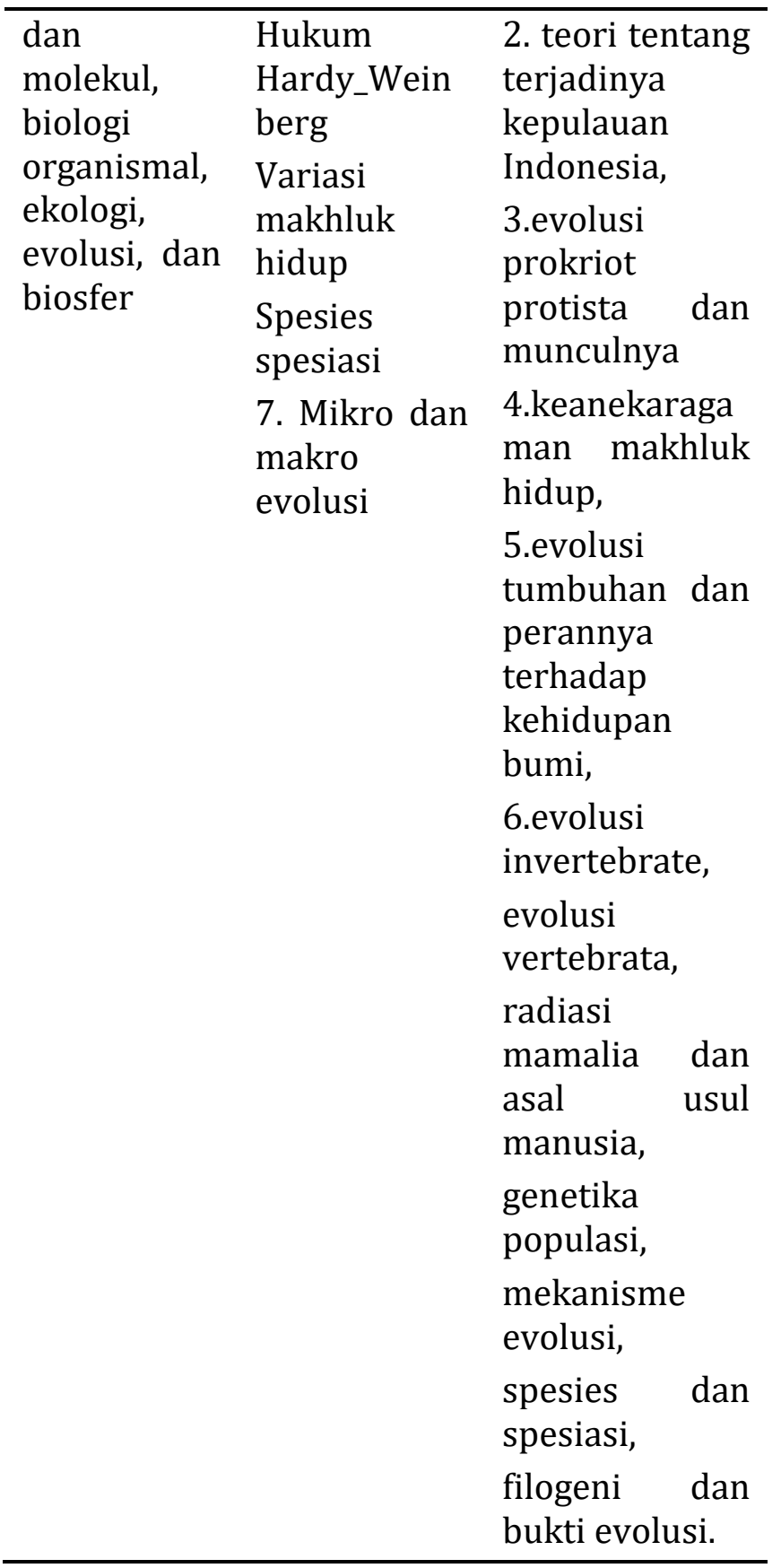

Proses pembelajaran ini memiliki target capaian bahwa mahasiswa program studi pendidikan Biologi dapat memahami dengan benar dan mendalam setiap konsepkonsep dasar pada materi perkuliahan evolusi di jurusan pendidikan Biologi. Oleh karena itu, materi disusun sedemikian rupa dari yang paling sederhana hingga yang paling kompleks untuk memudahkan pemetaan dan pengaturan tingkatan berfikir mahasiswa. Materi yang diajarkan di jurusan biologi ditempat penelitian ini dibagi menjadi beberapa kelompok materi yang disusun menurut tingkatan yang didasarkan pada standar isi dan kompetensi 
yang ditetapkan melalui analisis berdasarkan standar konsorsium biologi Indonesia (KOBI) dan Kerangka Kualifikasi Nasional Indonesia (KKNI). Sementara tingkat pemahaman mahasiswa terhadap konsep evolusi cukup tinggi kecuali menyangkut asal usul kehidupan, dimana pada materi asal usul kehidupan dan radiasi mamalia. Berdasarkan pada nilai yang diperoleh pada ujian tengah semester (bersumber dari dosen pengampu), nilai keseluruhan mahasiswa cukup tinggi untuk wilayah materi terdiri dari hakikat dan sejarah evolusi, asal usul makhluk hidup, seleksi alam dan Hukum Hardy-Weinberg. Akan tetapi soal yang diberikan oleh dosen pengampu mata kuliah sama sekali tidak meyasar kepada keyakinan dan pendapat mahasiswa terkait konsep. Semua pertanyaan yang diberikan oleh dosen dalam kegiatan ujian tengah semester bermuatan konten. Berdasarkan informasi dosen pengampu mata kuliah, sama sekali tidak ada kekhawatiran yang timbul selama ini akan pengetahuan evolusi mahasiswa dikarenakan selama ini semua nilai yang diperoleh mencapai skor maksimal yang diharapkan oleh dosen pengampu dan ditargetkan oleh kurikulum.

\section{Latar Belakang Keyakinan}

Mahasiswa yang merupakan informan kunci dalam penelitian ini adalah mahasiswa jurusan pendidikan biologi dengan latar belakang agama Islam (muslim). Selain mereka memiliki identitas sebagai seorang muslim, mereka sendiri memiliki lingkungan yang sangat mendukung keyakinannya yakni lingkungan yang kental atau sarat dengan nilai-nilai islam yang murni. Latar belakang budaya dan keyakinan tersebut tidak menjadikan key informan menjadi tertutup. Key informan maupun masyarakat sekitar sangat terbuka terhadap pengetahuan baru yang diberikan. Hal ini dapat dilihat dari kerukunan dan kebaikan perilaku mereka terhadap warga lainnya yang berbeda adat budaya maupun keyakinan dengan mereka. Fakta ini cukup sedikit menguak tentang kemungkinan bahwa tidak benar adanya keruncingan persepsi antara agama dan evolusi, akan tetapi tentu hal ini memerlukan pembuktian mendasar. Hal ini juga pernah diungkap oleh peneliti bahwa terdapat beberapa temuan peneliti yang berbeda pendapat memiliki argumen bahwa pengetahuan awal dianggap terlalu cepat diterima oleh masyarakat umum tentang evolusi versus penciptaan, meskipun pada hal ini banyak peneliti terus-menerus menegaskan hal sebaliknya dari pendapat mereka yang tidak terbiasa dengan literatur sejarah yang relevan. Klaim konflik besar antara sains dan agama terlalu dibesar-besarkan. Sebagai contoh, debat terkenal antara Uskup Oxford dan Thomas Huxley di Asosiasi Inggris untuk kemajuan ilmu pengetahuan tahun 1860 bukanlah tentang evolusi versus penciptaan atau bahkan sains versus kepercayaan. Sangat berbahaya melegitimasi suatu perubahan di zaman dimana apapun yang dipercaya memiliki efek social, karenanya sangat diperlukan pendampingan untuk pemahaman yang lebih baik dan benar (Devine, 1996; Helmi, 2019). Peneliti terdahulu menyajikan temuan-temuan dari studi kuasieksperimental yang mengevaluasi sikap dan kepercayaan para guru dalam menanggapi pembelajaran lintas-kurikuler Universitas tentang evolusi dan penciptaan yang menjembatani perspektif teologis biologis dan Kristen dimana evolusi dan penciptaan terlihat sangat berbenturan dalam pemahaman pendidik sekalipun (Konneman, 2018).

Sebelum kita dapat memahami pandangan agama seseorang, budaya dan masyarakat yang ada di dalamnya, maka terlebih dahulu kita harus mengetahui penjelasan tentang eksistensi mengenai agama itu sendiri. Agama adalah sebuah kepercayaan tertentu yang diyakini oleh sebagian besar masyarakat merupakan pedoman dalam kehidupan. Agama menyangkut tingkat keyakinan dan berbagai prakteknya (Bauto, 2014). Pada penelitian ini, agama yang dianut oleh mahasiswa adalah islam, dimana agama inilah yang 
kemudian menjadi dasar yang kuat bagi informan untuk melakukan penolakan terhadap satu diantara teori yang dikemukakan dalam kurikulum evolusi yakni mengenai teori evolusi yang berkaitan dengan mekanisme evolusi manusia. Akan tetapi terlepas dari teori evolusi manusia, keseluruhan informan menyatakan bahwa mereka menerima berbagai teori yang memiliki bukti secara ilmiah.

Hal yang mendasari mahasiswa menolak akan adanya manusia dan kera memiliki nenek moyang bersama atau dalam bahasa mereka "seketurunan" adalah keyakinan yang mereka anut tidak mengajarkan demikian. Mahasiswa mempedomani ajaran agama mereka yang mengajarkan bahwa manusia pertama yang ada dimuka bumi ini adalah seorang manusia yaitu Adam as dan diajarkan bahwa Adam adalah manusia sempurna secara fisik dan tidak sama sekali berkerabat dengan kera ataupun primata lainnya. Di dalam keyakinan mereka, Adam as adalah manusia pilihan Tuhan yang merupakan penyampai wahyu atau orang suci dalam konteks keyakinan.

\section{Pandangan Mahasiswa Terhadap Evolusi}

Berdasarkan data yang dimiliki oleh dosen yang diambil pada awal perkuliahan, didapati bahwa pengetahuan evolusi mahasiswa yang akan belajar materi evolusi sangat beragam. Akan tetapi dapat disimpulkan bahwa hampir semua mahasiswa sudah memiliki pengetahuan awal (dasar) dalam evolusi. Berdasarkan informasi dosen pengampu mata kuliah evolusi di prodi pendidikan biologi, kesulitan yang didapati dalam mengajar mata kuliah ini adalah kekhawatiran akan banyaknya miskonsepsi yang dibawa mahasiswa kedalam kelas. Miskonsepsi yang dimiliki oleh mahasiswa merupakan aku mulasi dari pengetahuan mereka sejak sebelum mereka mengikuti perkuliahan. Asumsi-asumsi yang mereka bawa telah terbangun sangat lama jauh sebelum perkuliahan dilaksanakan. Ketika perkuliahan berlangsung, dosen mendapakan sedikit kesulitan dalam mengajarkan karena pemahaman yang telah kuat sebelum pembelajaran sehingga diperlukan strategi khusus untuk dosen dapat membantu mahasiswa merubah atau meluruskan pemahaman konsepnya.

Gambar 1. Konsep Evolusi Mahasiswa

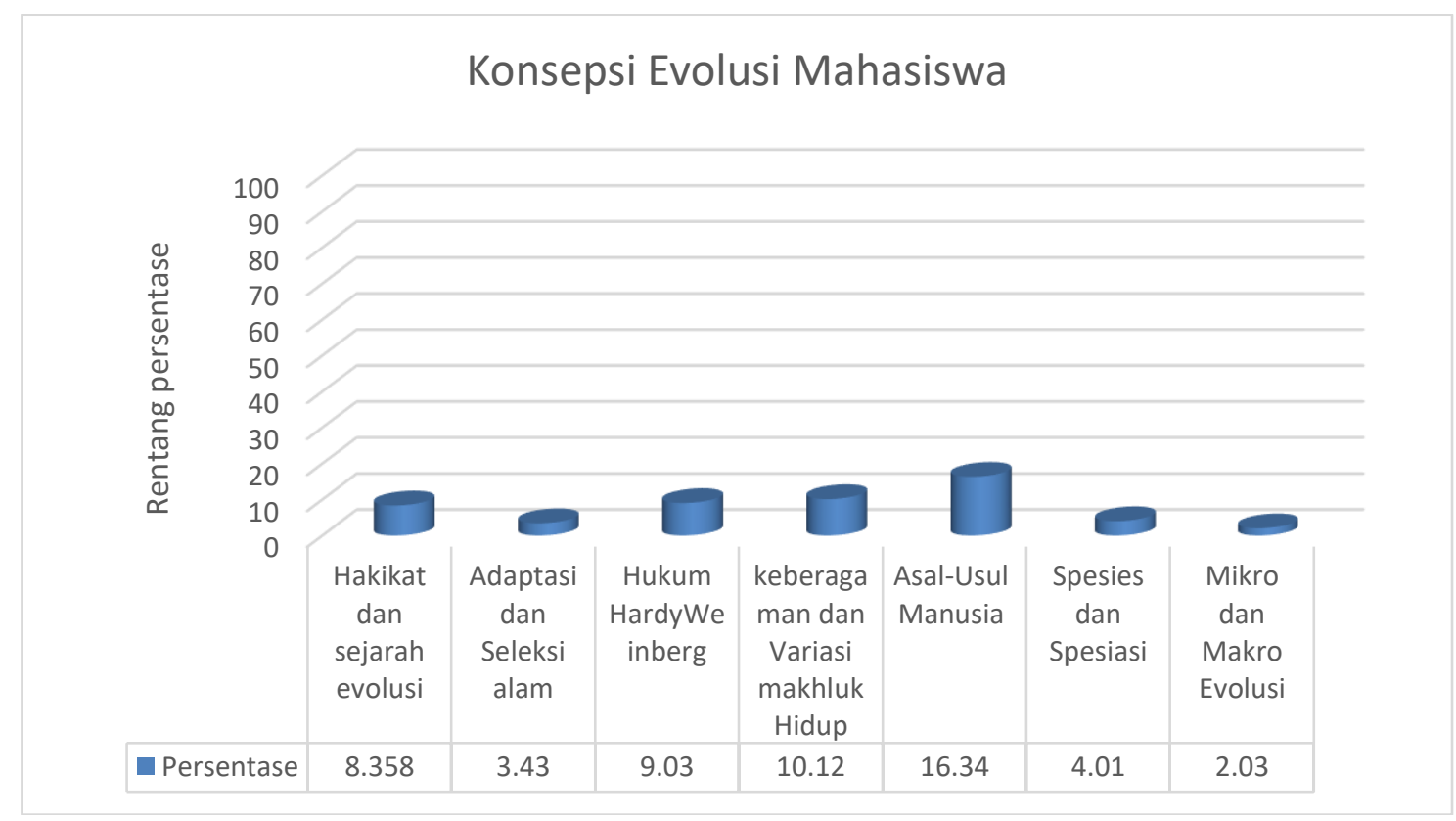


Berdasarkan data tersebut, dapat dilihat fakta bahwa masih terdapat cukup besar miskonsepsi siswa terhadap konsep asal usul kehidupan. Sebagian mahasiswa menyatukan antara pengetahuan yang didapat melalui berbagai literature sebagai kebenaran yang dipaksakan untuk diterima. Padahal, bab teori asal usul kehidupan pada kurikulum perkuliahan evolusi mengajarkan tentang pemikiran-pemikiran para peneliti terdahulu seperti Charles Robert Darwin, Jean Baptise Lamarck dan lainnya menyangkut evolusi, tidak serta merta mahasiswa harus menerimanya sebagai sebuah bukti kebenaran yang disangkut pautkan dengan keyakinan. Berdasarkan jawaban mahasiswa pada pertanyaan mengenai pustaka atau literature sumber yang mereka baca, sebagian besar mahasiswa mengakses materi tentang evolusi melalui internet. Terdapat hanya 2 (dua) orang atau $6.06 \%$ dari keseluruhan mahasiswa yang memiliki atau bahkan sempat membaca tentang teori evolusi langsung dari the origin of species karya Charles Darwin sedangkan 92,94\% lainnya membaca dari potongan-potongan atau cuplikan dari karya orang lain (bukan karya asli Darwin). Dalam hal ini mahasiswa mengakui pemikiran dan pemahaman mereka cukup terpengaruh oleh sudut pandang karya siapapun yang mereka pernah baca. Sebagian dari mahasiswa (30\%) memiliki buku (cetak maupun ebook) yang berkaitan dengan materi evolusi.

Menyangkut jawaban akan pertanyaan tentang hal-hal yang menjadi dasar bagi kebingungan mahasiswa atau hal yang mengawali ketidakpercayaan akan teori evolusi, jawaban mahasiswa dapat disimpulkan mengarah pada 4 (empat) hal pokok yaitu: 1) Seandainya saja spesies turun dari spesies lain dalam waktu yang lama, tentunya kita di mana-mana melihat bentuk transisi yang tak terhitung banyaknya. mengapa hal ini tidak terjadi?, 2) Mengapa tidak semua makluk hidup ditemukan bentuk evolusinya, mengapa terdapat spesies yang ditemukan secara utuh? 3) hal yang dianggap sangat mustahil, misalnya, struktur dan kebiasaan seekor kelelawar, dapat dibentuk oleh modifikasi beberapa hewan lain dengan kebiasaan dan struktur yang sangat berbeda, 4) ketika berkaitan dengan mikro evolusi, bagaimana kemudian gen flow dan genetic drift bisa dianggap sebagai proses evolusi. sedangkan selama ini, kelainan atau perubahan dari bentuk asalnya selalu menjadi lebih buruk (tidak menuju kesempurnaan) atau cacat.

Untuk pertanyaan wawancara yang menanyakan apakah evolusi penting untuk diajarkan pada program studi pendidikan biologi, 91\% mahasiswa menyatakan penting untuk adanya mata kuliah evolusi. Alasan yang dikemukakan mahasiswa tentang mengapa pentingnya evolusi bagi mahasiswa pendidikan biologi diantaranya adalah untuk member pemahaman mendalam agar mahasiswa tidak menjadi salah pemikiran atau miskonsepsi terhadap konsep dan teori evolusi. selain itu pendapat lainnya menyatakan pentingnya mata kuliah ini karena banyak hal penting mengenai ilmu-ilmu seperti genetika lanjut, adaptasi, sejarah waktu geologi dan lain sebagainya yang mahasiswa jurusan biologi memang harus mengetahui dan menguasai pengetahuan tersebut.

\section{Evolusi dan Penciptaan}

Evolusi dan penciptaan selalu mengalami pergolakan atau perang pemikiran dikalangan terdidik maupun masyarakat umum. Pada penelitian ini, mahasiswa jurusan pendidikan biologi sebagai informan juga melakukan penolakan terhadap asal usul manusia yang secara umum dipahami masyarakat yaitu berasal dari kera atau keturunan kera, hal terebut dianggap merupakan kontroversi mengakar yang terjadinya turun temurun dari generasi kegenerasi dalam berbagai kalangan. Padahal secara kultur budaya, masyarakat sebagai lingkungan tempat tinggal informan adalah lingkungan terpelajar dan kultur masyarakat yang berfikiran terbuka. Mahasiswa menganggap bahwa teori tersebut adalah sebuah 
kebohongan. Jawaban mereka akan pertanyaan yang menyangkut evolusi manusia terutama "common ancestor" adalah sebuah kemungkinan yang dianggap mustahil. Mahasiswa mengakui bahwa literatur yang mereka baca tidak dapat menunjukkan bukti secara ilmiah hal tersebut benar dan dapat dibuktikan. Mengenai hal ini, sebagian kalangan agama juga memiliki sudut pandangnya sendiri. Tercantum pada buku karangannya yang sangat fenomenal yaitu On The Origin of Species by means of the natural selection conception, Charles Robert Darwin menyatakan bahwa manusia berasal atau berevolusi dari nenek moyang yang sebenarnya bukanlah manusia (the human species evolved from ancestors who were not men). Pada kalimat ini agak diragukan bahwa apa yang dimaksud oleh Darwin dengan "ancestors". Jika ancestors dimaksudkan bahwa itu adalah nenek moyang, maka manusia pertama tentu bukanlah Adam seperti yang diyakini yaitu nabi Adam bahkan manusia tentu diyakini tidak mempunyai ayah, ibu, kakek, dan nenek, apabila ancestors dimaksudkan sebagai kekerabatan, tentunya dalam hal ini diartikan mempunyai hubungan kekerabatan dengan simpanse, gorila, orangutan dan kera. (Alam, 1984).

Darwin pun menyadari bahwa teorinya cukup menghadapi banyak masalah. Ia sempat mengakui hal ini pada bukunya di bab "Difficulties of the Theory"(Darwin, C.R, 1859). Berdasarkan kedua literatur tersebut, ditambah dengan beberapa buku sumber lainnya, dapat diambil kesimpulan bahwa dari sinilah pandangan miring dari mahasiswa tentang konsep nenek moyang bersama (common ancestor) adalah hal yang mustahil. Akan tetapi pandangan semacam ini tidak berlaku pada semua konsep dalam evolusi. Mahasiswa justru dapat menerima konsep lainnya.

Ketika berbicara adaptasi, keanekaragaman, genetika dan sebagainya sebagian besar mahasiswa yang dimana mereka adalah muslim, menyetujui dan menganggapnya sebagai suatu kebenaran.
Mengenai pemahaman mahasiswa terhadap asal usul manusia, mahasiswa mengakui bahwa mereka meragukan akan kebenaran teori tentang nenek moyang manusia yang berkerabat dengan kera tersebut. Akan tetapi meskipun mahasiswa mengaku menolak tentang common ancestor sebagai bagian dari konsep evolusi, sebagian besar $78 \%$ (tujuh puluh delapan persen) mahasiswa mengaku bahwa ia akan tetap mengajarkan konsep ini ketika mereka menjadi guru biologi suatu hari nanti. Pandangan ini didasarkan pada kekhawatiran mereka akan dampak dari posisinya sebagai guru jika mereka memilih untuk mengabaikan atau menolak mengajarkan. Kekhawatiran ini lebih kepada ketakutan mereka akan teguran dan peringatan terkait pekerjaan mereka sebagai guru nantinya. Sehingga semua itu terlepas dari pemahaman dan penerimaan karena hakikatnya mereka tetap tidak menerima secara keyakinan. Beberapa persen sisanya mengaku akan menyimpan teori ini dan tidak akan mengajarkannya sama sekali. Keputusan untuk tidak mengajarkan didasari oleh rasa tanggung jawab dan kekhawatiran akan memberikan penyesatan dan dampak negatif kepada anak didiknya kelak (perspektif mahasiswa). Pertanyaan terbesar dari mahasiswa adalah apakah makhluk hidup terjadi secara perlahan berubah antar spesies atau ada yang menciptakan secara tiba-tiba? Kedua hal ini yang kemudian masing-masing mahasiswa menyimpulkan sendiri jawabannya berdasarkan pengetahuan sendiri.

Pertanyaan mengenai bagaimana mahasiswa meyakini proses munculnya manusia dimuka bumi ini, mendapatkan jawaban yang sangat umum, dimana jawaban yang diberikan oleh keseluruhan mahasiswa adalah mereka percaya akan konsep penciptaan. Hal ini sejalan dengan peneliti terdahulu dimana pertentangan pemahaman tentang teori evolusi yang paling banyak adalah pemikiran bahwa evolusi meniadakan keberadaan Tuhan (Saputra, 2017). Hal ini menjadikan 
pemahaman yang dimiliki mahasiswa menjadi kuat dan tidak tergoyahkan. Pandangan akan ketidak setujuan terhadap "nenek moyang bersama" tidak dapat dirubah oleh dosen maupun oleh literatur sebagai acuan. Pandangan akan konsep ketuhanan menjadi dasar bagi mahasiswa untuk mempertahankan pendapat dan pemahamannya. Secara terus terang dosen mengakui bahwa lembaga dan dosen tidak dapat berbuat banyak dalam upaya mencegah kesalah pahaman konsep. Dosen mengakui bahwa tidak hanya mahasiswa bahkan dosen biologi antara satu dengan yang lainnya pun terkadang berbeda pendapat dan ada pula yang mengalami pertentangan batin antara keyakinan dan evolusi. hal ini menyiratkan seolah-olah evolusi menentang keyakinan.

\section{KESIMPULAN DAN IMPLIKASI}

\section{Kesimpulan}

Kesimpulan dalam penelitian ini adalah bahwa sebagian besar mahasiswa mempelajari dengan pemikiran terbuka akan konsep-konsep dalam perkuliahan evolusi. Mahasiswa hanya melakukan penolakan terhadap evolusi yang berkaitan dengan asal usul manusia. Konsep tentang evolusi sebagai the origin of species lebih diterima dibandingkan dengan pemahaman bahwa evolusi adalah sebagai the origin of life. Berdasarkan pertanyaan wawancara, didapatkan bahwa kesimpulan dari pandangan negatif mahasiswa terhadap evolusi mengarah pada 4 (empat) hal pokok yaitu: 1) Seandainya saja spesies berasal dari spesies lain dalam waktu yang lama, tentunya kita di mana-mana melihat bentuk transisi yang tak terhitung banyaknya. mengapa hal ini tidak terjadi?, 2) Mengapa tidak semua makluk hidup ditemukan bentuk evolusinya, mengapa terdapat spesies yang ditemukan secara utuh? 3) hal yang dianggap sangat mustahil, misalnya, struktur dan kebiasaan seekor kelelawar, dapat dibentuk oleh modifikasi beberapa hewan lain dengan kebiasaan dan struktur yang sangat berbeda, 4) ketika berkaitan dengan mikro evolusi, bagaimana kemudian gen flow dan genetic drift bisa dianggap sebagai proses evolusi. Sedangkan selama ini, kelainan atau perubahan dari bentuk asalnya selalu menjadi lebih buruk (tidak menuju kesempurnaan) atau cacat. Beberapa hal tersebut yang kemudian menjadi inti utama keyakinan mahasiswa untuk menolak sebagian dari konsep di dalam cakupan materi evolusi.

\section{Implikasi}

Rekomendasi dan implikasi disampaikan kepada program studi tempat dilakukannya penelitian ini, agar kiranya sedini mungkin mengidentifikasi kemungkinan terjadi miskonsepsi pada pemahaman mahasiswanya mengenai konsep-konsep dalam evolusi sehingga kemudian juga dapat disiapkan pencegahan atau model perubahan konsepsi yang tepat untuk perbaikan konsepsi siswa. Selanjutnya disampaikan kepada dosen pengampu mata kuliah evolusi agar peduli dengan konsepsi mahasiswanya terhadap evolusi dan tidak hanya berfokus pada penguasaan konsep saja. Kemudian kepada peneliti selanjutnya, agar dapat mengambil bagian dalam upaya mengurai benang kusut antara kesalah pahaman dan perang pendapat antara teori evolusi dan penciptaan sehingga dapat ditemukan solusi perbaikannya agar mahasiswa dimanapun tidak menjadi korban dari mendapat imbas perang pemikiran ini (evolution versus creation).

\section{DAFTAR PUSTAKA}

Alam, S. (1984). Evolusi Manusia dan Konsepsi Islam. Bandung: Risalah.

Athanasiou, K. (2014). Evolution theory teaching and learning: what conclusions can we get from comparisons of teachers' and students' conceptual ecologies in greece and turkey?. Eurasia, 11(4):842852 
Bauto, L.M. (2014). Perspektif Agama Dan Kebudayaan Dalam Kehidupan Masyarakat Indonesia (Suatu Tinjauan Sosiologi Agama). Jurnal Pendidikan Ilmu Sosial, 23(2): 11-25

Creswell, J.W. \& Clarck, V.P. (2007). Designing and Conduting Mixed Methods Research. London: Sage Publications

Darwin, C.R. (1859). The Origin of Species. New York: D. Appleton \& Company

Devine, P.E. (1996). Creation and Evolution. Journal Religious Studies, 32(03): 325337

H Helmi. Rustaman, N.Y., Tapilouw, F.S. \& Hidayat, T. (2018). Preconception analysis of evolution on pre-service biology teachers using certainty of response index. J.Phys.: Conference Series, 1157 (2019): 1-7

Hermann, R.S. (2016). Elementary Education Majors' Views on Evolution: A Comparison of Undergraduate Majors Understanding of Natural Selection and Acceptance of Evolution. Electronic Journal of Science Education, 20(6): 21-44
Konnemann, C., Höger, C., Asshoff, R., Hammann, M \& Rieß, W. (2018). A Role for Epistemic Insight in Attitude and Belief Change? Lessons from a CrossCurricular Course on Evolution and Creation. Research in Science Education, 48(6): 1187-1204

Luthfi, M.J \& Khusnuryani, A. (2005). Agama Dan Evolusi: Konflik Atau Kompromi? Kaunia, 1(1): 1-19

Owens, D.A., Butler, A.M., Aguero, T.H., Newman, K.M., Van Booven, D., King, M.L. (2017). High-throughput analysis reveals novel maternal germline RNAs crucial for primordial germ cell preservation and proper migration. Development, 144 (2017): 292-304

Saputra, A. (2017). Persepsi Mahasiswa Calon Guru Biologi tentang Pembelajaran Materi Evolusi di SMA: Studi Kasus Mahasiswa Pendidikan Biologi FKIP Universitas Sebelas Maret Surakarta. Bioeducation Journal, 1(1): 1-9

Yin, Robert K. (2009). Studi Kasus: Desain dan Metode. Jakarta : Rajagrafindo Persada. 